\title{
The potential inhibitory impact of curcumin, epigallocatechin gallate and their combinations on infectious bronchitis virus in vivo
}

\author{
Fadwa Amin', Sabry Tamam², Abdou Allayeh ${ }^{3 *}$ and Mai Raslan1 \\ ${ }^{1}$ Biotechnology and Life Sciences Department, Faculty of Postgraduate Studies for Advanced Sciences, \\ Beni-Suef University, Egypt. \\ ${ }^{2}$ Virology Department, Faculty of Veterinary Medicine, Beni-Suef University, Egypt. \\ ${ }^{3}$ Virology Lab 176, Environmental Research Division, National Research Centre (NRC), El-Buhouth St., Dokki, $12622-$ \\ Cairo, Egypt. \\ Email: abdou.kamal@nawah-scientific.com \\ Received 9 June 2021; Received in revised form 23 August 2021; Accepted 3 December 2021
}

\begin{abstract}
Aims: Infectious bronchitis virus (IBV) is a highly contagious, acute viral respiratory disease that mostly affects chickens. The poultry sector has suffered enormous losses as a result of IBV. Currently, live attenuated vaccines are routinely used to prevent and control IBV. However, due to the enormous genetic variety, vaccinations are becoming ineffective, with low cross-protection effects among vaccine serotypes. The present study aimed at investigating the possible antiviral effects of curcumin, epigallocatechin gallate (EGCG) and their mixtures against IBV in vivo.

Methodology and results: Curcumin, EGCG and their combinations were administered to infected and uninfected chicken groups and viral load titers were determined by real-time PCR. The clinical symptoms of both the negative and positive control groups were also compared. Finally, the trachea tissues of each group were examined histopathologically. According to our findings, the viral titer and the clinical signs dropped significantly during the pretreatment infection procedure. Curcumin, EGCG and their combinations also show significant antiviral activities.

Conclusion, significance and impact of study: This study clearly shown that natural compounds and their combinations, such as curcumin or/and ECGC can reduce viral pathogenicity in vivo, suggesting that they might have therapeutic implications in the poultry sector.
\end{abstract}

Keywords: Infectious bronchitis virus, curcumin, EGCG, coronvirus, real time PCR

\section{INTRODUCTION}

The infectious bronchitis virus (IBV) is the causative agent of infectious bronchitis (IB), a highly contagious, acute viral respiratory illness that affects chicken. Globally, IBV has a significant direct negative impact on the poultry sector due to high mortality, poor egg quality and meat output, as well as a significant indirect impact owing to obstacles in IBV prevention (Liang et al., 2019; Wu et al., 2019). IBV is a member of the Coronaviridae family and the genus Coronaviruses. The IBV genome is surrounded by a positive sense RNA strand. Its replication is distinguished by a high rate of genetic recombination $(\mathrm{Wu}$ et al., 2019). IBV infects chickens of all ages, however it causes severe sickness in newborn chickens and the severity lessens with age (Liu et al., 2005). IBV can be transferred to chickens by direct contact with aerosols as well as indirect contact with contaminated equipment, egg packing material, farm utensils and litter items (OIE, 2012). Currently, live attenuated vaccines are routinely utilized for IBV prevention and control. However, due to the high rate of genetic variability among IBV strains, vaccinations are becoming ineffective with poor crossprotection effects among various serotypes (Yan et al., 2018). Meanwhile, because of a lack of concerted effort to avoid IBV, as well as a lack of adequate surveillance and the introduction of foreign strains to battle IBV in specific locations, IBV prevention and control has become extremely challenging. As a result, finding efficient antiviral substances for IBV prevention is critical.

Turmeric, curcuma longa, is an essential plant in traditional Chinese medicine because it contains curcumin [1,7-bis(4-hydroxy-3-methoxyphenyl)-1,6heptadiene-3,5-dione], a key active component (Wei et al., 2017). The Food and Drug Administration (FDA) has determined that it is generally regarded as safe (GRAS). During the clinical trials, a healthy amount of curcumin up to $12 \mathrm{~g}$ /day was known to be safe for human consumption without provoking adverse effects (Gupta et al., 2013). Curcumin has been recognized as analgesic, antioxidant, 
antimicrobial, anti-inflammatory and anticarcinogenic in many previously published reports (Çıkrıkçı et al., 2008). Curcumin, as antimicrobial agent has antibacterial activity against a wide range of bacterial strains, parasites and fungi (Moghadamtousi et al., 2014; Ali and Banerjea, 2016). Several studies with curcumin against human viruses such as herpes simplex virus (HSV), hepatitis C virus (HCV) and respiratory syncytial virus (RSV) have been undertaken (Yang et al., 2016b; Wei et al., 2017). According to Yang et al. (2014), curcumin bioavailability in tissues is quite low due to its poor absorption, rapid metabolism, chemical instability and rapid systemic elimination; hence the inclusion of various substances such as piperine or liposome can boost that bioavailability (Kakaral et al., 2010). The processes involving interference with viral life cycle step(s) have been outlined in Table 1 based on the literature on curcumin's antiviral action.

Green tea, on the other hand, is one of the world's most popular beverages. Catechin, epicatechin, epigallocatechin, gallocatechin and epigallocatechin gallate are quaternary polyphenolic substances found in green tea that have been shown to help reduce lipid peroxidation in the liver, kidney and blood vessels (Okuda et al., 1983). These natural polyphenols have piqued the interest of researchers due to the possible health advantages stemming from their antioxidant properties. Among the five types of catechins, epigallocatechin-3gallate (EGCG), accounts for roughly $59 \%$ of the total polyphenols in dried green tea leaves (Schinzari et al., 2015). Many reactive oxygen/nitrogen species (ROS/RNS) such as superoxide radical anions, peroxyl and hydroxyl radicals, singlet oxygen, nitric oxide and peroxynitrite are scavengers for EGCG. EGCG has the potential to capture peroxyl radicals and disrupt the chain reaction of free radicals, so halting lipid peroxidation (Thangapandiyan and Miltonprabu, 2014). Several studies have been undertaken using green tea catechins or EGCG against human viruses such as adenovirus (Ad). Table 1 summarizes the processes involving interference with viral life cycle steps in the literature on green tea catechins' antiviral activity.

Table 1: A summary of antiviral activities of curcumin and green tea against several human viruses, as reported in the literatures.

\begin{tabular}{|c|c|c|c|}
\hline Compound & Virus & Antiviral activity mode & Reference \\
\hline \multirow{12}{*}{ Curcumin } & Human immunodeficiency virus & Replication inhibitors & Ali and Banerjea (2016) \\
\hline & $\begin{array}{l}(\mathrm{HIV}) \\
\text { Hepatitis C virus (HCV) }\end{array}$ & Adsornt & Angaakusuma et al (2014) \\
\hline & Human cytomegalovirus (I & Adsorption inhibitors & Lv et al. (2015) \\
\hline & Epstein-Barr virus (EBV) & Replication inhibitors & Ferreira et al. (2015) \\
\hline & Bovine herpesvirus $1(\mathrm{BH}$ & Adsorption inhibitors & Zhu et al. (2015) \\
\hline & Chikungunya virus & Adsorption inhibitors & Narayanan et al. (2012) \\
\hline & Ebola virus & rption inhibitors & Setlur et al. (2017) \\
\hline & Enterovirus 71 (EV71) & Replication inhibitors & Qin et al. (2014) \\
\hline & Rift Valley fever virus ( $R$ & Replication inhibitors & Narayanan et al. (2012) \\
\hline & Human norovirus (HuNoV) & Adsorption inhibitors & Yang et al. (2016a) \\
\hline & Respiratory syncytial virus (RSV) & Virucidal effect & Yang et al. (2016b) \\
\hline & Influenza A virus (IAV) & Adsorption/replication inhibitors & Chen et al. (2010; 2013) \\
\hline \multirow{16}{*}{$\begin{array}{l}\text { Green tea } \\
\text { or } \\
\text { EGCG }\end{array}$} & Hepatitis B virus (HBV) & Adsorption/replication inhibitors & Xu et al. (2016) \\
\hline & Herpes simplex virus (HSV) & Adsorption/replication inhibitors & Colpitts and Schang (2014) \\
\hline & Epstein-Barr virus (EPV) & Adsorption/replication inhibitors & Liu et al. (2013) \\
\hline & HIV & Adsorption/replication inhibitors & Hartjen et al. (2012) \\
\hline & Hepatitis C virus (HCV) & Adsorption/replication inhibitors & Calland et al. (2015) \\
\hline & Influenza virus & Adsorption/replication inhibitors & Yang et al. (2014) \\
\hline & Dengue virus (DENV) & Adsorption/replication inhibitors & Carneiro et al. (2016) \\
\hline & Chikungunya virus (CHIKV) & Entry inhibitor & Weber et al. (2015) \\
\hline & Human T-lymph virus type 1 & Inhibition of viral gene expression & Harakeh et al. (2014) \\
\hline & Rotavirus & Entry inhibitor & Mukoyama et al. (1991) \\
\hline & Enterovirus EV71 & Entry inhibitor & Ho et al. (2009) \\
\hline & Ebola virus (EBOV) & Release/replication inhibitors & Reid et al. (2014) \\
\hline & $\begin{array}{l}\text { Porcine reproductive \& respiratory } \\
\text { syndrome virus (PRRSV) }\end{array}$ & Entry inhibitor & Zhao et al. (2015) \\
\hline & $\begin{array}{l}\text { Viral hemorrhagic septimia virus } \\
\text { (VHSV) }\end{array}$ & Replication inhibitor & Estepa and Coll (2015) \\
\hline & Grass carp reovirus (GCRV) & Replication inhibitor & Wang et al. (2016) \\
\hline & Zika virus(ZIKV) & Adsorption/replication inhibitors & Carneiro et al. (2016) \\
\hline
\end{tabular}


Natural antimicrobials or plant extracts (phenolics, flavonoids, tannins) can have a negative influence on oxidative stress, assisting the organism in protecting itself from the harmful effects of reactive oxygen species (Hwang et al., 2016). Natural antimicrobial combinations have previously been shown to be effective in reducing bacterial infections in chicken and mouse animal models (Sima et al., 2018; Stratakos et al., 2019). We propose that combining natural antimicrobials can successfully minimize clinical signs of sickness while having no negative impact on animal health. The activity of curcumin, ECGC and their combination against IBV in vivo was investigated in this work.

\section{MATERIALS AND METHODS}

\section{Viruses and natural compounds}

Infectious bronchitis virus (IBV) was graciously donated by Egypt's Animal Health Research Institute. IBV was propagated in pathogen-free embryonated chicken eggs that were 10 days old. The allantoic fluids were extracted, titrated and kept at $-80{ }^{\circ} \mathrm{C} 48 \mathrm{~h}$ after infection. The median infectious dosage of embryos (EID ${ }_{50}$ ) was estimated using a previously described approach (Reed and Muench, 1938). The EGCG and curcumin were purchased from Sigma-Aldrich, St. Louis, MO and kept at $4{ }^{\circ} \mathrm{C}$ until further use.

\section{Preparation of pepperin}

A total of $10 \mathrm{~g}$ of black pepper powder were extracted in a solvent extractor for two hours with $150 \mathrm{ml}$ of $100 \%$ ethanol. The solution was filtered and concentrated in a $60{ }^{\circ} \mathrm{C}$ water bath. With constant stirring, $10 \mathrm{ml}$ of $10 \%$ alcoholic potassium hydroxide was added to the filtrate. The insoluble residue was filtered and the alcoholic solution was allowed to stand overnight before being filtered through a membrane filter. Pepperin was isolated and mixed with curcumin to increase curcumin bioavailability.

\section{Cytotoxicity assay}

The cytotoxicity test was performed on accessible cell lines in our laboratory, including Hep-2 and vero cell lines (Nawah-Scientific, Cairo, Egypt). The cells were cultured in Dulbecco's Modified Eagle Medium (DMEM) with 10\% FBS, 100 units $/ \mathrm{mL}$ penicillin and $100 \mathrm{mg} / \mathrm{mL}$ streptomycin. Cultures were kept at $37^{\circ} \mathrm{C}$ in a humidified environment with $5 \% \mathrm{CO}_{2}$. To make a stock solution, each chemical was pre-solubilized in dimethyl sulphoxide (DMSO) at $37{ }^{\circ} \mathrm{C}$. Serial two-fold dilutions were conducted $(100,50,25,12.5,6.25,3.125,1.5625 \mu \mathrm{g} / \mathrm{mL})$. The sulforhodamine $B$ colorimetric (SRB) test was used to assess cell viability. Confluent monolayers of each cell line were cultivated for $24 \mathrm{~h}$ in 96 well microtitre plates. Cells were cultured in triplicate with varying doses of the test substances for $72 \mathrm{~h}$ at $37{ }^{\circ} \mathrm{C}$ in a $\mathrm{CO}_{2}$ atmosphere. After that, $150 \mu \mathrm{L}$ cold $10 \%$ trichloro acetate (TCA) was added to each well and incubated at $4{ }^{\circ} \mathrm{C}$ for $1 \mathrm{~h}$. Plates were washed four times with slow-running tap water before being blotted dry with paper towels. $100 \mu \mathrm{L}$ of $0.057 \%(\mathrm{w} / \mathrm{v})$ SRB solution was added and incubated at room temperature for $30 \mathrm{~min}$ before washing with $1 \%$ $(\mathrm{v} / \mathrm{v})$ acetic acid to remove unbound pigment followed by air dry of the plates. The SRB stain was dissolved in each well with $200 \mu \mathrm{L}$ of $10 \mathrm{mM}$ Tris base solution. Finally, the $\mathrm{OD}$ was measured at $570 \mathrm{~nm}$ in a microplate reader (BMG LABTECH® FLUOstar Omega, Germany) and cell survival percentages were estimated using the following formula:

Survival rate $=\mathrm{OD}_{570}$ Drug/OD570 Control (untreated) $\times$ $100 \%$

\section{Study design and experimental model}

This study followed the rules of the Local Ethical and Animal Welfare Committee of the Faculty of Postgraduate Studies for Advanced Sciences at Beni-Suef University in Egypt. One-day old chickens $(n=100)$ were purchased from a nearby hatchery and raised to the fourth week of life. Under typical management settings, 90 two weeks old mixed-sex hens were maintained in separate high efficiency particulate arresting isolators with wire flooring. Each chicken received commercial chicken feed containing $23 \%$ crude proteins, $4.93 \%$ fats, $70 \%$ carbohydrates and $3027 \mathrm{kcal} / \mathrm{kg}$ calories. The chickens were sorted into nine groups of ten chickens $(A, B, C, D$, $E, F, G, H$ and I). Curcumin and EGCG were diluted in $1 \%$ carboxy methyl cellulose and sprayed into the diet (Naderi et al., 2014). Group A served as the untreated and uninfected negative control. The positive control group, Group B was infected with IBV. Groups C and D were infected with IBV and treated with curcumin or EGCG at doses of $5 \mathrm{mg} / \mathrm{kg}$ and $400 \mathrm{mg} / \mathrm{kg}$, respectively. Group E was infected with IBV and given a diet containing $2.5 \mathrm{mg} / \mathrm{kg}$ curcumin and $200 \mathrm{mg} / \mathrm{kg}$ EGCG. The $F$ and $G$ groups were fed for five days with curcumin and EGCG at $5 \mathrm{mg} / \mathrm{kg}$ and $400 \mathrm{mg} / \mathrm{kg}$ of feed, respectively, before being infected with IBV. Group H was given a five-day treatment with $2.5 \mathrm{mg} / \mathrm{kg}$ curcumin and $200 \mathrm{mg} / \mathrm{kg}$ EGCG before being infected with IBV. The tested concentrations of curcumin and EGCG were selected based on previously published reports (Umar et al., 2016; Aydogan et al., 2018). At the second week of life, $0.1 \mathrm{ml}$ of IBV $\left(10^{5.6}\right.$ EID5o/bird) was injected intra-nasally (IN) into infected groups. Acyclovir (40 mg/kg) was given to Group I as a positive control. Table 2 summarizes the study's design.

\section{Clinical signs}

The chickens were monitored daily for clinical indications such as illness, sneezing, nasal discharge, diarrhea, head swelling and death. Clinical indications were quantified and expressed as a proportion of total chicken population (Table 3). The percentage difference was utilized to determine the efficacy of curcumin, EGCG and their 
Table 2: The study groups utilized to evaluate the in vivo antiviral activity of curcumin and EGCG against IBV in chicken. The table indicates the number of birds in each group, the concentration of each drug employed and the alternative modes for chicken treatment by compounds.

\begin{tabular}{|c|c|c|}
\hline Group & Number & Treatment \\
\hline Group A & 10 & No compounds + No virus \\
\hline Group B & 10 & $10^{5.6} \mathrm{EID}_{50} / 100 \mu \mathrm{l}$ of IBV \\
\hline Group C & 10 & $10^{5.6}$ EID $_{50} / 100 \mu \mathrm{l}$ of IBV + curcumin $(5 \mathrm{mg} / \mathrm{kg}$ feed $)$ \\
\hline Group D & 10 & $10^{5.6} \mathrm{EID}_{50} / 100 \mu \mathrm{I}$ of IBV + EGCG $(400 \mathrm{mg} / \mathrm{kg}$ feed $)$ \\
\hline Group E & 10 & $10^{5.6} \mathrm{EID}_{50} / 100 \mu \mathrm{l}$ of IBV + (50\% curcumin/EGCG mixture $)$ \\
\hline Group F & 10 & Curcumin $(5 \mathrm{mg} / \mathrm{kg}$ feed $)+10^{5.6} \mathrm{EID}_{50} / 100 \mu \mathrm{l}$ of IBV \\
\hline Group G & 10 & EGCG $(400 \mathrm{mg} / \mathrm{kg}$ feed $)+10^{5.6} \mathrm{EID}_{50} / 100 \mu \mathrm{l}$ of IBV \\
\hline Group H & 10 & $(50 \%$ curcumin/EGCG mixture $)+10^{5.6} \mathrm{EID}_{50} / 100 \mu \mathrm{l}$ of IBV \\
\hline Group 1 & 10 & $10^{5.6}$ EID $50 / 100 \mu$ of IBV + Acyclovir $(40 \mathrm{mg} / \mathrm{kg}$ feed $)$ \\
\hline
\end{tabular}

Chicken were classified into 9 groups as follow: Groups A, B and I were negative and positive controls, respectively; Groups C, D and $\mathrm{E}$ were challenged by IBV then treated with different compounds; Groups $\mathrm{F}, \mathrm{G}$ and $\mathrm{H}$ are treated with different compounds and then challenged by IBV.

Table 3: The clinical signs scoring in all chicken groups. The number of chickens in each group that have one or more clinical signs represents the incidence percentage of each sign inside the group.

\begin{tabular}{|c|c|c|c|c|c|}
\hline \multirow[b]{2}{*}{ Group } & \multicolumn{3}{|c|}{ Clinical signs } & \multirow[b]{2}{*}{ Odds ratio } & \multirow[b]{2}{*}{$p$-value } \\
\hline & Sneezing & $\begin{array}{l}\text { Mouth breathing } \\
\text { and trachea rale }\end{array}$ & Conjunctivitis & & \\
\hline$A$ & NA & NA & NA & NA & NA \\
\hline$B$ & $10 / 10$ & $8 / 10$ & $6 / 10$ & & \\
\hline C & $8 / 10$ & $5 / 10$ & $5 / 10$ & 1.333 & 0.4773 \\
\hline$D$ & $8 / 10$ & $6 / 10$ & $2 / 10$ & 1.500 & 0.3266 \\
\hline$E$ & $5 / 10$ & $4 / 10$ & $2 / 10$ & 2.182 & 0.0805 \\
\hline $\mathrm{F}$ & $2 / 10$ & $1 / 10$ & NA & 24.000 & $0.0018^{*}$ \\
\hline$G$ & $2 / 10$ & NA & NA & 12.000 & $0.0014^{*}$ \\
\hline $\mathrm{H}$ & $1 / 10$ & & NA & 24.000 & $0.0025^{*}$ \\
\hline I & $2 / 10$ & NA & NA & 12.000 & $0.0014^{*}$ \\
\hline
\end{tabular}

${ }^{*}$ Significant difference between test group and control group $(p<0.05)$. NA means no clinical sign appeared.

Table 4: Sequences of the primers and probe used in this study.

\begin{tabular}{llll}
\hline Name & Gene & Sequence & Reference \\
\hline Forward Primer & & 5'-ATGCTCAACCTTGTCCCTAGCA-'3 & Meir et al. (2010) \\
Reverse Primer & NGene & 5'-TCAAACTGCGGATCATCACGT-'3 & \\
Probe & 5'-FAM-TTGGAAGTAGAGTGACGCCCAAACTTCA-TAMRA-'3 & \\
\hline
\end{tabular}

mixtures in reducing clinical symptoms of illness. Chickens from each group were humanely slaughtered after 28 days and tracheal samples were preserved at $80{ }^{\circ} \mathrm{C}$ for viral RNA quantification through RT-qPCR and histological exams.

\section{Quantification of viral titer using RT-qPCR}

The RNA was isolated using the QIAamp viral RNA isolation kit (Qiagen, Valencia, CA) according to the manufacturer's instructions. The viral titer was measured using the previously established quantitative real time reverse transcriptase polymerase chain reaction (qRTPCR) (Meir et al., 2010). In brief, RT-qPCR experiment targeting the IBV N gene was carried out with the RTqPCR Kit (Qiagen, Düsseldorf, Germany) using the primers and probe (Table 4). The quantitative RT-qPCR reactions were carried out using the following temperature program on a Real-Time PCR machine (Stratagene MX3005P). For primer sets, the reverse transcriptase step settings were $50{ }^{\circ} \mathrm{C}$ for $30 \mathrm{~min}, 94{ }^{\circ} \mathrm{C}$ for $15 \mathrm{~min}$, followed by 40 cycles of $94^{\circ} \mathrm{C}$ for $15 \mathrm{sec}$ and $60^{\circ} \mathrm{C}$ for 45 $\mathrm{sec}$. With RNA isolated from the challenge virus, standard curve was generated with viral control and the amount of

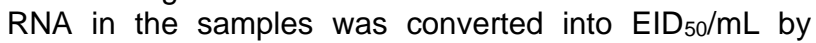
interpolation (Umar et al., 2015). The virus titer was presented by the mean $\pm S D$ of the virus titer per $\mathrm{mL}$. 


\section{Histopathology examination}

Representative trachea samples were preserved in $10 \%$ formalin solution for $48 \mathrm{~h}$ before being processed by paraffin embedding, sectioned 5 and stained with Haematoxylin and Eosin (H\&E) according to Bancroft and Gamble (2002). The trachea was then inspected microscopically and scored using the prior histopathologic scoring system for trachea (Levisohn et al., 1986; Todd et al., 1991) with slight modifications. The following morphological alterations were observed: mucous epithelial cilia loss, balloon-like cell extrusion and necrotic exfoliation of the mucous layer, lymphocyte and heterophil infiltration in the submucosal layer, hyperemia and/or bleeding.

\section{Statistical analysis}

GraphPad software was used for statistical analysis. The data were reported as mean $\pm S D$. $p$-values less than 0.05 were deemed statistically significant. Viral titers obtained were analyzed for significance using student's $t$ - test. An ANOVA test was used to compare the percentage reduction to the untreated control.

\section{RESULTS}

\section{The cytotoxicity of curcumin and EGCG on vero and Hep-2 cell lines}

The vitality of the cells was determined using an optical microscope and validated using the SRB technique. The cytotoxicity was computed using GraphPad Prism software (version 5.01) nonlinear regression analysis by graphing log inhibitor versus normalized response. The cytotoxic concentration of the compounds to cause death to $50 \%\left(C_{50}\right)$ of viable vero cells of curcumin and EGCG were found to be 93.19 and $88.82 \mu \mathrm{g} / \mathrm{ml}$, respectively. For Hep-2 cells, the $\mathrm{CC}_{50}$ of curcumin and EGCG were found to be 52.86 and $41.90 \mu \mathrm{g} / \mathrm{mL}$, respectively. As indicated in Figure 1, the cell survival rate evaluated by the SRB technique was close to $100 \%$, indicating that there was no substantial influence on the cells.
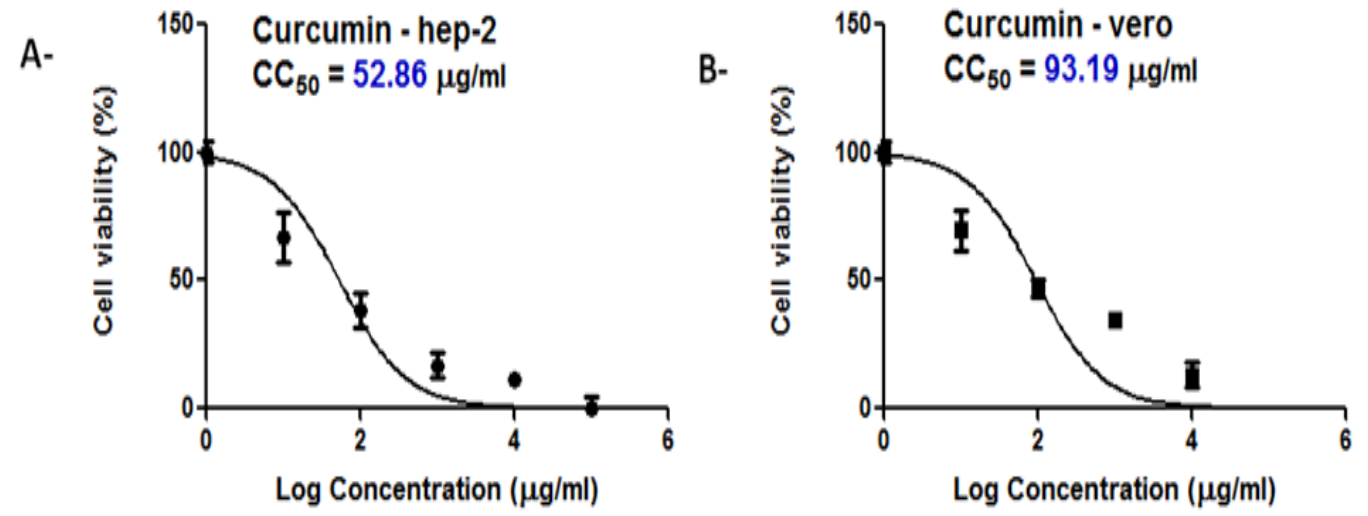

D-

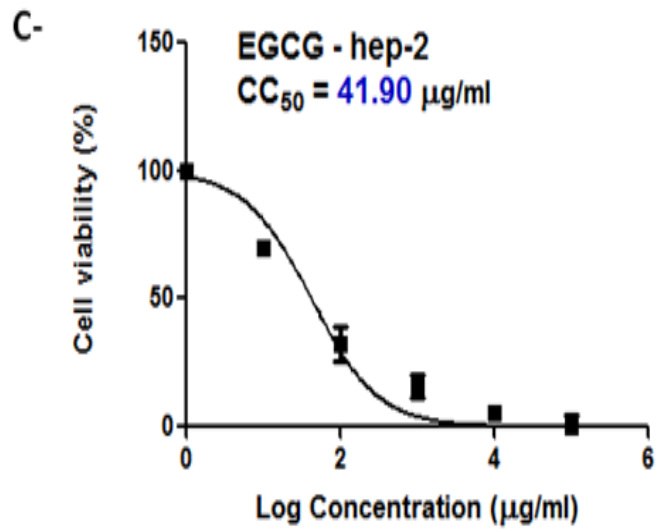

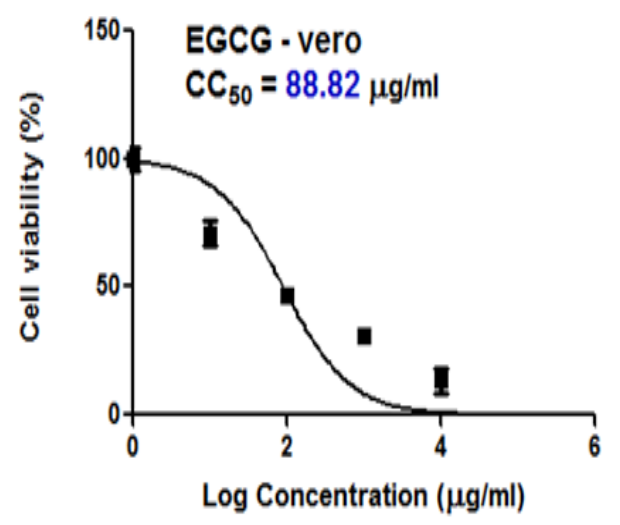

Figure 1: Effect of curcumin and EGCG on the viability of Hep-2 and vero cell lines. Sulforhodamine B colorimetric (SRB) staining was used to assess cell viability. The survival rates of Hep-2 and vero cells were given at different concentrations of curcumin and EGCG, and cell survival rates of more than $50 \%$ was considered to be the maximum non-toxic concentration of curcumin and EGCG. Data are expressed as mean \pm SD of 3 independent experiments. 


\section{Effect of curcumin and EGCG on the clinical signs of IBV in chicken groups}

In order to quantify the favorable benefits stated above, we extensively examined the clinical symptoms in the challenged chicken during curcumin or EGCG treatment following 6 days of viral infection (Table 3). The A, G, H and I groups had no symptoms, the $F$ group had light symptoms, the $E$ group had moderate symptoms and the $B, C$ and $D$ groups had severe symptoms. Sneezing, tracheal wet rale, mouth breathing and conjunctivitis (coughing, ruffled feathers and frequent shaking signals) were noted in IBV-infected groups. In the $\mathrm{C}$ and $\mathrm{F}$ groups, the effectiveness of curcumin administration was assessed before and after viral infection, in contrast to the control group B. While the efficacy of EGCG therapy was compared in the $D$ and $G$ groups before and after viral infection. The efficacy of the curcumin/EGCG combination was also examined in the $E$ and $H$ groups before and after viral infection. Sneezing was decreased in the curcumin-treated group before viral infection (F) compared to the curcumin-treated group after viral infection (C), (50\% vs. $80 \%$, respectively). Sneezing was reduced also in the EGCG-treated groups before $(\mathrm{G})$ and after viral infection (D), (20\% vs. $80 \%$, respectively). For sneezing in mixed curcumin/EGCG groups before $(\mathrm{H})$ and after $(E)$ treatment, there is also markedly change (10\% vs. $50 \%$, respectively). For mouth breathing and conjunctivitis clinical symptoms, all treated curcumin, EGCG and mixed groups before viral infection were significantly reduced more than all groups treated with tested compounds after viral infection as shown in Table 3.

Effect of the curcumin and EGCG on the viral load in the trachea of chickens with IBS

We then investigated the antiviral effects of curcumin and EGCG in a chicken model infected with the IBS virus. As shown in Table 5, the viral RNA copies in group B was approximately $\log _{10} 6.6394$ copies/g tissue, with a considerable decrease in groups $F, G$ and $H\left(\log _{10} 3.3922\right.$, $\log _{10} 3.5822$ and $\log _{10} 3.5807$ copies/g tissue, respectively) similar to the Acyclovir-treated control group (I). The viral load levels were reduced to those found in the Acyclovirtreated group (I) $\left(\log _{10}{ }^{3.581} \mathrm{copies} / \mathrm{g}\right.$ tissues). The levels of significance were computed using group I as a reference. These findings suggest that curcumin, EGCG and their combination reduced the virus load in tracheal tissue, particularly during pretreatment prior to viral infection by reduction fold up to $10^{3}$, while groups $(C, D$ and $E$ ) have a minor reduction fold on viral load up to $10^{1}$.

\section{Effect of the curcumin and EGCG on the pathological injury trachea of chickens with IBS}

The ratings for the distribution and degree of the aforementioned lesions in each chicken's trachea are classified as follows: 0 , no lesion; 1 , lesion represented in less than $10 \%$ of tissue involvement; 2, lesion represented in 10-50\% involvement; 3, lesion represented in 50-90\% involvement; and 4, lesion represented in more than $90 \%$ involvement (Table 6). The majority of the tracheal cilia in the IBV-infected group (B) broke off sever mucous epithelial cilia loss, balloon-like cell extrusion and necrotic exfoliation of the mucous layer, lymphocyte and heterophil infiltration in the submucosal layer. The mucosal epithelial cells exfoliated, vanished and the submucosal structure was jumbled (Figure 2-A). While moderated pathogenicity in some areas were observed in the treatment groups (C, E and D), where compounds were injected after viral infection (Figures 2$B, C$ and D), the mucosa is thickened and infiltrated, with degeneration and desquamation of epithelial cells. For treatment groups ( $F, G$ and $H)$, where the compounds were injected prior to viral infection (Figures 2-E, F and G), mild pathogenicity in some areas were seen, the mucosa is thickened with degeneration and desquamation of epithelial cells. Totally, the tracheal lesions in the treated groups prior to viral infection were grade 1, the same as in the Acyclovir-treated group (I). They all had low vacuolar degeneration, with only a few mononuclear cells in the submucosal tissue.

Table 5: The average of RNA copies per group using quantitative real time PCR.

\begin{tabular}{|c|c|c|c|c|c|}
\hline Group & $\begin{array}{l}\text { Average titer } \\
\text { (EID } 50 / \mathrm{mL} \text { ) }\end{array}$ & $\log _{10}$ & Reduction fold & Odds ratio & $p$-value \\
\hline Group A (Negative control) & - & - & - & - & - \\
\hline Group B (Positive control) & $4358700 \pm 128$ & $10^{6.6394}$ & - & - & - \\
\hline Group C (Virus + Curcumin) & $313850 \pm 165$ & $10^{5.4967}$ & $10^{1}$ & 13.8878 & $0.0001^{*}$ \\
\hline Group D (Virus + EGCG) & $535780 \pm 558$ & $10^{5.729}$ & $10^{1}$ & 8.1352 & $0.0001^{*}$ \\
\hline Group E (Virus + Curcumin/EGCG) & $39394 \pm 442$ & $10^{4.5954}$ & $10^{2}$ & 110.6438 & $0.0001^{*}$ \\
\hline Group F (Curcumin + virus) & $2468 \pm 131$ & $10^{3.3922}$ & $10^{3}$ & 1766 & $0.0001^{*}$ \\
\hline Group G (EGCG + virus) & $3822 \pm 107$ & $10^{3.5822}$ & $10^{3}$ & 1140 & $0.0001^{*}$ \\
\hline Group H (Curcumin/EGCG + virus) & $3808 \pm 80$ & $10^{3.5807}$ & $10^{3}$ & 1144 & $0.0001^{*}$ \\
\hline Group I (Virus + Acyclovir) & $3811 \pm 180$ & $10^{3.581}$ & $10^{3}$ & 1144 & $0.0001^{*}$ \\
\hline
\end{tabular}

Each number represents the mean \pm SD of three independent experiments.

${ }^{*}$ Significant difference between test group and control group $(p<0.05)$ 

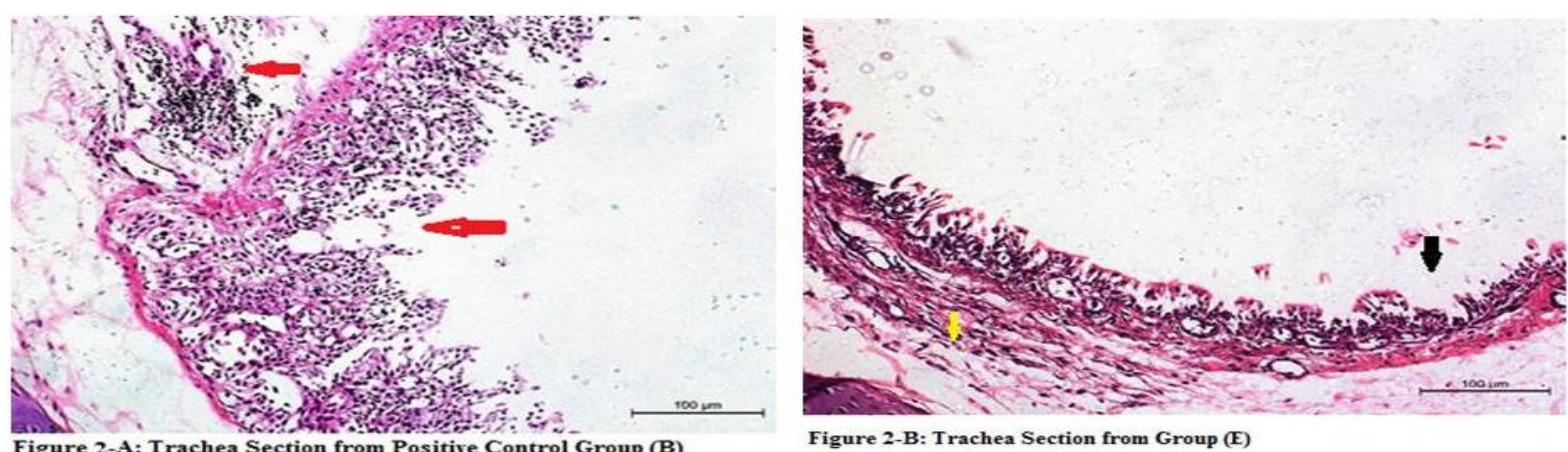

Figure 2-A: Trachea Section from Positive Control Group (B)
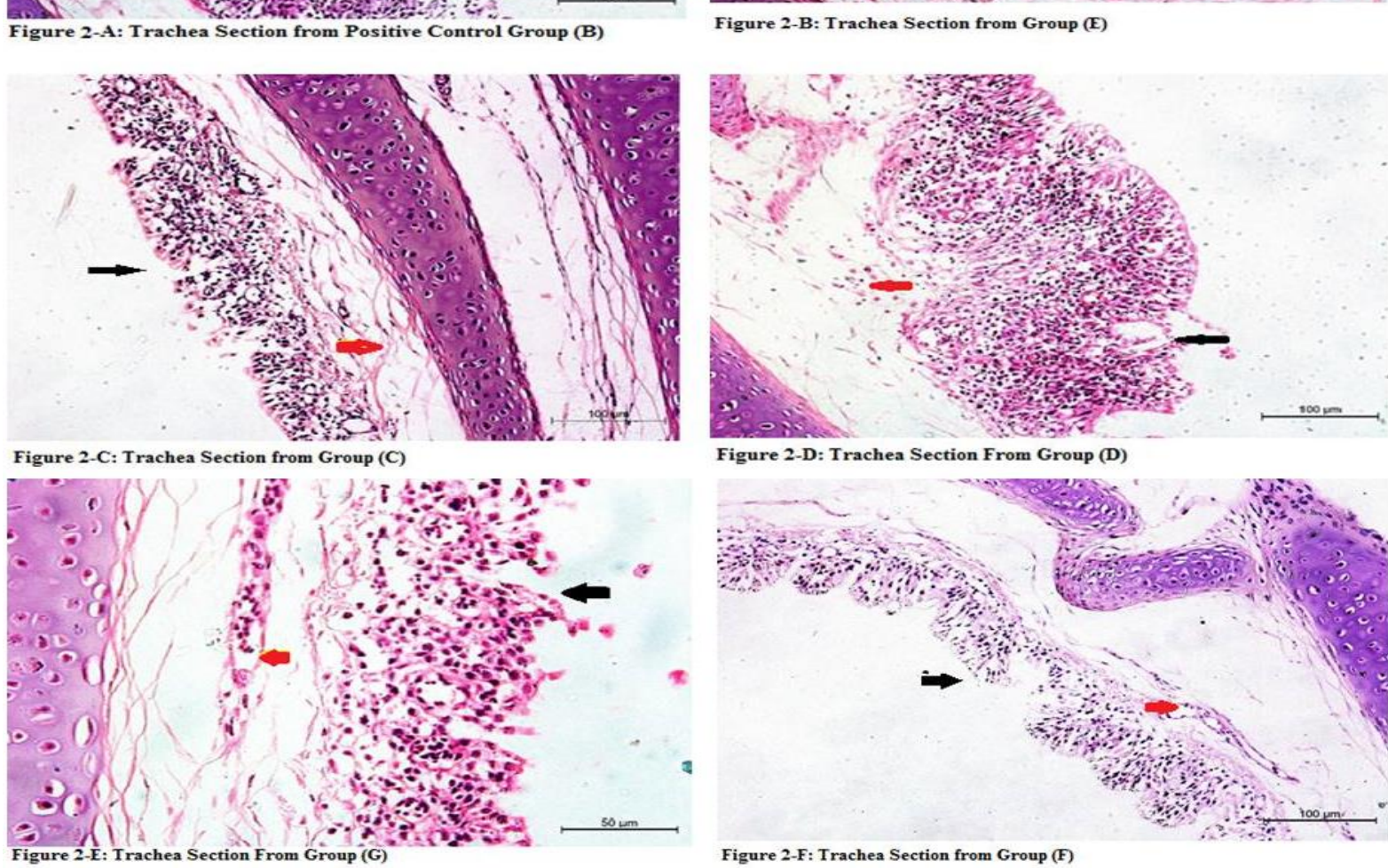

Figure 2-D: Trachea Section From Group (D)

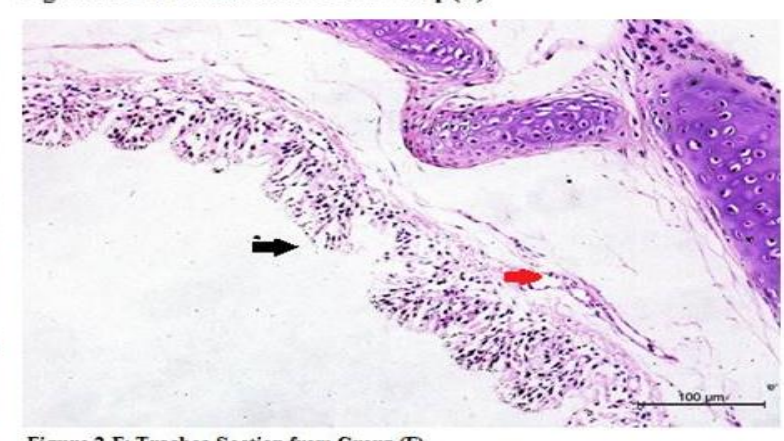

Figure 2-F: Trachea Section from Group (F)
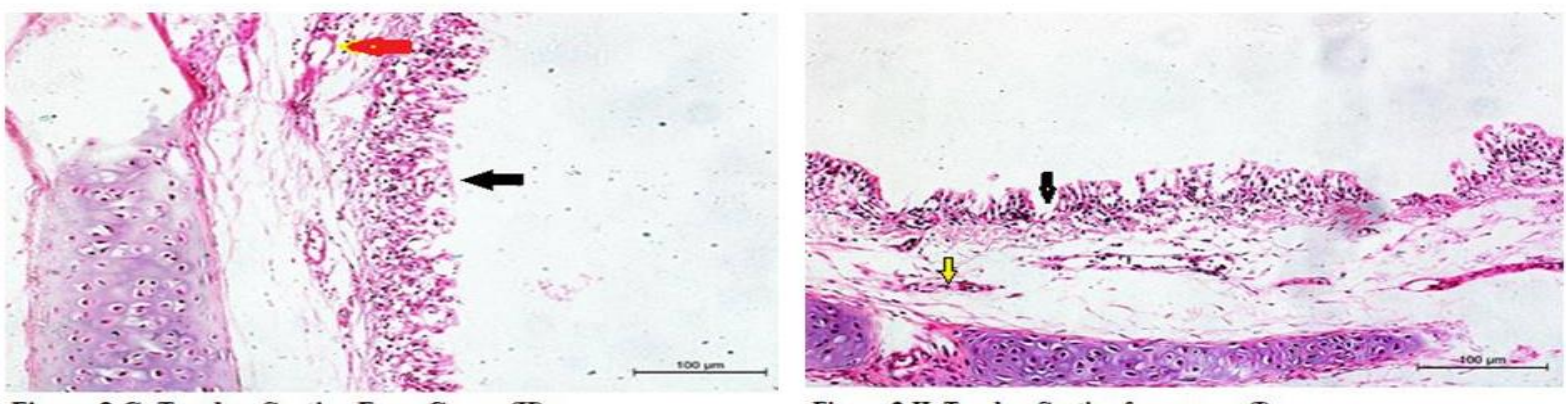

Figure 2-H: Trachea Section from group (I)

Figure 2: Effects of curcumin and EGCG on IBV-induced tracheal injury of chicken. Trachea was processed for histological evaluation at day 6 after viral infection. Black arrow refers to the degree of loss cilia and degeneration of epithelial cell, while red arrow indicates mucosal inflammatory infiltrates or epithelial hyperplasia infiltration. (2-A) Trachea section from the IBV-infected group B shows sever mucous epithelial cilia loss, balloon-like cell extrusion and necrotic exfoliation of the mucous layer, lymphocyte and heterophil infiltration in the submucosal layer. (2-B), (2-C) and (2-D) show moderated pathogenicity and the mucosa is thickened, infiltrated with degeneration and desquamation of epithelial cells. (2-E), (2-F) and (2-G) show mild pathogenicity in some areas and the mucosa is thickened with degeneration and desquamation of epithelial cells. $(2-\mathrm{H})$ The trachea section from treated group I shows low vacuolar degeneration, with only a few mononuclear cells in the submucosal tissue. 
Malays. J. Microbiol. Vol 18(1) 2022, pp. xxx-xxx

DOI: http://dx.doi.org/10.21161/mjm.211200

Table 6: Scoring of trachea tissues histopathology.

\begin{tabular}{ccccc}
\hline Group & $\begin{array}{c}\text { Loss of cilia or } \\
\text { epithelial cells }\end{array}$ & $\begin{array}{c}\text { Degeneration or necrosis of } \\
\text { epithelial cells }\end{array}$ & $\begin{array}{c}\text { Mucosal inflammatory infiltrates or } \\
\text { epithelial hyperplasia }\end{array}$ & $\begin{array}{c}\text { Grade } \\
\text { A }\end{array}$ \\
B & + & - & - & 0 \\
C & ++ & ++++ & +++ & 3 \\
D & + & ++ & + & 2 \\
E & + & ++ & ++ & 2 \\
F & + & + & + & 2 \\
G & + & - & + & 1 \\
H & + & - & + & 1 \\
I & + & - & + & 1 \\
\hline
\end{tabular}

(-) indicates no apparent clinical disease sign in trachea tissue; + Mild, ++ Moderate, +++Severe.

\section{DISCUSSION}

There are several known mutant strains of infectious bronchitis virus (IBV), resulting in more varied and complicated genotypes (Laconi et al., 2019). It is difficult to prevent or control IBV infection due to poor crossprotection across various serotypes of vaccines. As a result, developing an effective antiviral medication is a critical strategy for IBV therapy. Previous research has revealed that curcumin's antiviral action is mediated by a variety of mechanisms. Curcumin, for example, inhibits the Japanese encephalitis virus via a dysregulated ubiquitin-proteasome pathway (Dutta et al., 2009). The inhibition of NF-B signalling by curcumin limits Rift Valley fever viral multiplication (Narayanan et al., 2012). Curcumin inhibits SREBP-1, an essential transcription factor in sterol synthesis regulation that is susceptible to Hepatitis C virus (Kim et al., 2010).

We reported here how IBV may be suppressed by curcumin or/and EGCG, components of turmeric and green tea, respectively, using three approaches: qRTPCR, clinical symptoms and histological investigation. In this study, two alternative experimental designs were investigated: (1) pretreatment of chickens prior to infection and (2) direct treatment of virus-infected chickens. Our findings suggested that curcumin or/and ECGC may markedly reduce the amount of IBV titer, the clinical manifestations of this respiratory disease and the pathological destruction of the trachea produced by IBV in chickens, particularly in pretreatment of hens prior to infection experiment design.

In particular, with $0.1 \mathrm{~mL}$ of $10^{5.6}$ EID ${ }_{50}$ infective units of IBV inoculated into each chicken, the curcumin, EGCG and curcumin/EGCG mixture treatments reduced viral load $\left(\log _{10} 3.3922, \log _{10} 3.5822\right.$ and $\log _{10} 3.5807$ copies/g tissue, respectively) compared to infected non-treated chickens $\left(\log _{10} 6.6394\right)$, representing a 3 -log reduction of infective units during pretreatment mechanism. This might be because curcumin or EGCG decreased virus-cell binding considerably in the cells of infected chickens. These findings are consistent with previous reports on the antiviral properties of curcumin and EGCG. Curcumin was demonstrated to have antiviral activity against zika and chikungunya viruses by inhibiting viral-cell binding in a pretreatment experiment according to (Mounce et al., 2017). Additionally, curcumin was shown to impact HCV replication through binding and fusion (Anggakusuma et al., 2014), similar to the results we have obtained. EGCG proved to be more likely to inhibit early stages of infections, such as attachment, according to (Ogawa et al., 2020).

Chickens are an important natural host of the infectious bronchitis virus which targets the upper respiratory tract and intensive virus replication leads to clinical manifestation characteristic signs such as sneezing and conjunctivitis. When curcumin or/and ECGC were included in the diet of chicken, the characteristic clinical signs were significantly decreased by curcumin or/and ECGC during the pretreatment mechanism. The efficacy of curcumin or/and ECGC to prevent respiratory illness progression was validated by the reduced presence of clinical symptoms in infected birds, as in Table 2. The improved immune and antiviral activities of the studied substances, as reported earlier, may account for the decreased severity of clinical symptoms in EGCG and curcumin fed chickens (Chen et al., 2013; Moghadamtousi et al., 2014; Umar et al., 2015). As a result, it's reasonable to believe that the compounds studied can reduce the severity of IBV clinical indications, particularly when administered prior to viral infection. To further confirm the inhibitory effect of curcumin or/and ECGC on infected chickens, the pathological injury of trachea tissues was examined. Our results confirmed the curcumin or/and ECGC had anti-IBV activity, such as reducing the alleviating the pathological injury of trachea caused by IBV in chickens (Figure 2). When came to evaluation of antiviral effects, Acyclovir was used as a control drug. The inhibitory effect of $5 \mathrm{~g} / \mathrm{kg}$ curcumin and $400 \mathrm{mg} / \mathrm{kg}$ EGCG was comparable to that of $40 \mathrm{mg} / \mathrm{kg}$ Acyclovir in vivo. Alterations associated with IBV infection were observed specifically in trachea ranged from loss of cilia, degeneration of epithelial cells, to necrosis and mucosal infiltrate. However, for most of these abnormalities, severity was lower in the curcumin- or EGCG-treated groups before viral infection. 


\section{CONCLUSION}

The poultry industry needs to find and test new and natural antiviral combinations that might minimize the severity of clinical symptoms and maybe prevent viral infections. Our research convincingly demonstrated that antiviral drugs like curcumin and/or ECGC, as well as their combination, can reduce IBV pathogenicity in vivo.

\section{ACKNOWLEDGEMENTS}

The authors are gratefully acknowledging the financial support from Beni-Suef University, University Performance Development Center, Support and Project Finance Office.

\section{REFERENCES}

Ali, A. and Banerjea, A. C. (2016). Curcumin inhibits HIV-1 by promoting Tat protein degradation. Scientific Reports 6, 27539.

Anggakusuma, Colpitts, C. C., Schang, L. M., Rachmawati, H., Frentzen, A., Pfaender, S., Behrendt, P., Brown, R. J. P., Bankwitz, D., Steinmann, J., Ott, M., Meuleman, P., Rice, C. M., Ploss, A., Pietschmann, T. and Steinmann, E. (2014). Turmeric curcumin inhibits entry of all hepatitis C virus genotypes into human liver cells. Gut 63(7), 1137-1149.

Aydogan, I., Karslı, M. A., Başalan, M., Yıldırım, E., Çınar, M., Şen, G. and Sümer, T. (2018). Effects of supplemental epigallocatechin gallate in the diet of broilers exposed to fluoride intoxication. Biological Trace Element Research 186, 258-266.

Bancroft, J. D. and Gamble, M. (2002). Theory and Practice of Histological Techniques, 5th edn. Churchill Livingstone, London.

Calland, N., Sahuc, M., Belouzard, S., Pène, V., Bonnafous, P., Mesalam, A. A., Deloison, G., Descamps, V., Sahpaz, S., Wychowski, C., Lambert, O., Brodin, P., Duverlie, G., Meuleman, P., Rosenberg, A. R., Dubuisson, J., Rouillé, Y. and Séron, K. (2015). Polyphenols inhibit hepatitis $C$ virus entry by a new mechanism of action. Journal Virology 89(19), 10053-10063.

Carneiro, B. M., Batista, M. N., Braga, A. C., Nogueira, M. L. and Rahal, P. (2016). The green tea molecule EGCG inhibits Zika virus entry. Virology 496, 215-218.

Chen, D. Y., Shien, J. H., Tiley, L., Chiou, S. S., Wang, S. Y., Chang, T. J., Lee, Y. J., Chan, K. W. and Hsu, W. L. (2010). Curcumin inhibits influenza virus infection and haemagglutination activity. Food Chemicals 119(4), 1346-1351.

Chen, T. Y., Chen, D. Y., Wen, H. W., Ou, J. L., Chiou, S. S., Chen, J. M., Wong, M. L. and Hsu, W. L. (2013). Inhibition of enveloped virus's infectivity by curcumin. PLoS One 8(5), e62482.

Colpitts, C. C. and Schang, L. M. (2014). A small molecule inhibits virion attachment to heparan sulfate- or sialic acid-containing glycans. Journal of Virology 88(14), 7806-7817.

Çıkrıkçı, S., Mozioğlu, E. and Yılmaz, H. (2008). Biological activity of curcuminoids isolated from Curcuma longa. Records of Natural Products 2(1), 1924.

Dutta, K., Ghosh, D. and Basu, A. (2009). Curcumin protects neuronal cells from Japanese encephalitis virus-mediated cell death and also inhibits infective viral particle formation by dysregulation of ubiquitinproteasome system. Journal of Neuroimmune Pharmacology 4(3), 328-337.

Estepa, A. and Coll, J. (2015). Inhibition of SERPINe1 reduces rhabdoviral infections in zebrafish. Fish and Shellfish Immunology 47(1), 264-270.

Ferreira, V. H., Nazli, A., Dizzell, S. E., Mueller, K. and Kaushic, C. (2015). The anti-inflammatory activity of curcumin protects the genital mucosal epithelial barrier from disruption and blocks replication of HIV-1 and HSV-2. PLoS One 10(4), e0124903.

Gupta, S. C., Patchva, S. and Aggarwal, B. B. (2013). Therapeutic roles of curcumin: Lessons learned from clinical trials. AAPS Journal 15(1), 195-218.

Harakeh, S., Diab-Assaf, M., Azar, R., Abdulla Hassan, H. M., Tayeb, S., Abou-El-Ardat, K., Damanhouri, G. A., Qadri, I., Abuzenadah, A., Chaudhary, A., Kumosani, T., Niedzwiecki, A., Rath, M., Yacoub, H., Azhar, E. and Barbour, E. (2014). Epigallocatechin-3-gallate inhibits tax-dependent activation of nuclear factor kappa B and of matrix metalloproteinase 9 in human T-cell lymphotropic virus-1 positive leukemia cells. Asian Pacific Journal of Cancer Prevention 15(3), 1219-1225.

Hartjen, P., Frerk, S., Hauber, I., Matzat, V., Thomssen, A. Holstermann, B., Hohenberg, H., Schulze, W., Zur Wiesch, J. S. and van Lunzen, J. (2012). Assessment of the range of the HIV-1 infectivity enhancing effect of individual human semen specimen and the range of inhibition by EGCG. AIDS Research and Therapy 9(1), 2.

Ho, H. Y., Cheng, M. L., Weng, S. F., Leu, Y. L. and Chiu, D. T. (2009). Antiviral effect of epigallocatechin gallate on enterovirus 71. Journal of Agricultural and Food Chemistry 57(14), 6140-6147.

Hwang, K. A., Hwang, Y. J. and Song, J. (2016). Antioxidant activities and oxidative stress inhibitory effects of ethanol extracts from Cornus officinalis on raw 264.7 cells. BMC Complementary and Alternative Medicine 16, 196.

Kakarala, M., Brenner, D. E., Korkaya, H., Cheng, C., Tazi, K., Ginestier, C., Liu, S., Dontu, G. and Wicha, M. S. (2010). Targeting breast stem cells with the cancer preventive compounds curcumin and piperine. Breast Cancer Research and Treatment 122(3), 777785.

Kim, K., Kim, K. H., Kim, H. Y., Cho, H. K., Sakamoto, N. and Cheong, J. (2010). Curcumin inhibits hepatitis $C$ virus replication via suppressing the Akt-SREBP-1 pathway. FEBS Letters 584(4), 707-712. 
Laconi, A., Listorti, V., Franzo, G., Cecchinato, M., Naylor, C., Lupini, C. and Catelli, E. (2019). Molecular characterization of whole genome sequence of infectious bronchitis virus 624I genotype confirms the close relationship with Q1 genotype. Transbound and Emerging Diseases 66(1), 207-216.

Levisohn, S., Dykstra, M. J., Lin, M. Y. and Kleven, S. H. (1986). Comparison of in vivo and in vitro methods for pathogenicity evaluation for Mycoplasma gallisepticum in respiratory infection. Avian Patholology 15(2), 233-246.

Liang, J. Q., Fang, S., Yuan, Q., Huang, M., Chen, R. A., Fung, T. S. and Liu, D. X. (2019). N-linked glycosylation of the membrane protein ectodomain regulates infectious bronchitis virus-induced ER stress response, apoptosis and pathogenesis. Virology 531 , 48-56.

Liu, S., Li, H., Chen, L., Yang, L., Li, L., Tao, Y., Li, W., Li, Z., Liu, H., Tang, M., Bode, A. M., Dong, Z. and Cao, Y. (2013). (-)-Epigallocatechin-3-gallate inhibition of Epstein-Barr virus spontaneous lytic infection involves ERK1/2 and PI3-K/Akt signaling in EBVpositive cells. Carcinogenesis 34(3), 627-637.

Liu, S., Lu, H., Zhao, Q., He, Y., Niu, J., Debnath, A. K., Wu, S. and Jiang, S. (2005). Theaflavin derivatives in black tea and catechin derivatives in green tea inhibit HIV-1 entry by targeting gp41. Biochimica et Biophysica Acta 1723 (1-3), 270-281.

Lv, Y., Gong, L., Wang, Z., Han, F., Liu, H., Lu, X. and Liu, L. (2015). Curcumin inhibits human cytomegalovirus by downregulating heat shock protein 90. Molecular Medicine Reports 12(3), 4789-4793.

Meir, R., Maharat, O., Farnushi, Y. and Simanov, L. (2010). Development of a real-time TaqMan® ${ }^{\circledR}$ T PCR assay for the detection of infectious bronchitis virus in chickens, and comparison of RT-PCR and virus isolation. Journal of Virological Methods 163(2), 190-194.

Moghadamtousi, S. Z., Abdul Kadir, H., Hassandarvish, P., Tajik, H., Abubakar, S. and Zandi, K. (2014). A review on antibacterial, antiviral, and antifungal activity of curcumin. BioMed Research International 2014, Article ID 186864.

Mounce, B. C., Cesaro, T., Carrau, L., Vallet, T. and Vignuzzi, M. (2017). Curcumin inhibits Zika and chikungunya virus infection by inhibiting cell binding. Antiviral Research 142, 148-157.

Mukoyama, A., Ushijima, H., Nishimura, S., Koike, H., Toda, M., Hara, Y. and Shimamura, T. (1991). Inhibition of rotavirus and enterovirus infections by tea extracts. Japanese Journal of Medical Science and Biology 44(4), 181-186.

Naderi, M., Akbari, M. R., Asadi-Khoshoei, E., Khaksar, K. and Khajali, F. (2014). Effects of dietary inclusion of turmeric (Curcuma longa) and cinnamon (Cinnamomum verum) powders on performance, organs relative weight and some immune system parameters in broiler chickens. Poultry Science Journal 2(2), 153-163.
Narayanan, A., Kehn-Hall, K., Senina, S., Lundberg, L., Duyne, R. V., Guendel, I., Das, R., Baer, A., Bethel, L., Turell, M., Hartman, A. L., Das, B., Bailey, C. and Kashanchi, F. (2012). Curcumin inhibits Rift Valley fever virus replication in human cells. Journal of Biological Chemistry 287(40), 33198-33214.

Ogawa, M., Shimojima, M., Saijo, M. and Fukasawa, M. (2020). Several catechins and flavonols from green tea inhibit severe fever with thrombocytopenia syndrome virus infection in vitro. Journal of Infection and Chemotherapy 27(1), 32-39.

OIE, World Organisation for Animal Health (2012). Avian influenza. In: Manual of Diagnostic Tests and Vaccines for Terrestrial Animals. World Organisation for Animal Health, France. pp. 436-452.

Okuda, T., Kimura, Y., Yoshida, T., Hatano, T., Okuda, H. and Arichi, S. (1983). Studies on the activities of tannins and related compounds from medicinal plants and drugs. I. Inhibitory effects on lipid peroxidation in mitochondria and microsomes of liver. Chemical and Pharmaceutical Bulletin 31(5), 1625-1631.

Qin, Y., Lin, L., Chen, Y., Wu, S., Si, X., Wu, H., Zai, X., Wang, Y., Tong, L., Pan, B., Zhong, X., Wang, T., Zhao, W. and Zhong, Z. (2014). Curcumin inhibits the replication of enterovirus 71 in vitro. Acta Pharmaceutica Sinica B 4(4), 284-294.

Reed, L. J. and Muench, H. (1938). Simple method of estimating fifty per cent endpoints. American Journal of Epidemiology 27(3), 493-497.

Reid, S. P., Shurtleff, A. C., Costantino, J. A., Tritsch, S. R., Retterer, C., Spurgers, K. B. and Bavari, S. (2014). HSPA5 is an essential host factor for Ebola virus infection. Antiviral Research 109, 171-174.

Schinzari, V., Barnaba, V. and Piconese, S. (2015). Chronic hepatitis B virus and hepatitis $C$ virus infections and cancer: Synergy between viral and host factors. Clinical Microbiology and Infection 21(11), 969-974.

Setlur, A. S., Naik, S. Y. and Skariyachan, S. (2017). Herbal lead as ideal bioactive compounds against probable drug targets of Ebola virus in comparison with known chemical analogue: A computational drug discovery perspective. Interdisciplinary Sciences: Computational Life Sciences 9(2), 254-277.

Sima, F., Stratakos, A. C., Ward, P., Linton, M., Kelly, C., Pinkerton, L., Stef, L., Gundogdu, O., Lazar, V. and Corcionivoschi, N. (2018). A novel natural antimicrobial can reduce the in vitro and in vivo pathogenicity of T6SS positive Campylobacter jejuni and Campylobacter coli chicken isolates. Frontiers in Microbiology 9, 2139.

Stratakos, A. C., Linton, M., Ward, P., Campbell, M., Kelly, C., Pinkerton, L., Stef, L., Pet, L., Stef, D., lancu, T., Theodoridou, K., Gundogdur, O. and Corcionivoschi, N. (2019). The antimicrobial effect of a commercial mixture of natural antimicrobials against Escherichia coli 0157:H7. Foodborne Pathogen and Disease 16(2), 119-129.

Thangapandiyan, S. and Miltonprabu, S. (2014). Epigallocatechin gallate supplementation protects 
against renal injury induced by fluoride intoxication in rats: Role of Nrf2/HO-1 signaling. Toxicology Reports 1, 12-30.

Todd, D. A., John, E. and Osborn, R. A. (1991). Tracheal damage following conventional and highfrequency ventilation at low and high humidity. Critical Care Medicine 19(10), 1310-1316.

Umar, S., Shah, M, A. A., Munir, M. T., Yaqoob, M., Fiaz, M., Anjum, S., Kaboudi, K., Bouzouaia, M., Younus, M., Nisa, Q., Iqbal, M. and Umar, W. (2016). Synergistic effects of thymoquinone and curcumin on immune response and anti-viral activity against avian influenza virus (H9N2) in turkeys. Poultry Science 95(7), 1513-1520.

Umar, S., Younus, M., Rehman, M. U., Aslam, A., Shah, M. A. A., Munir, M. T., Hussain, S., Iqbal, F., Fiaz, M. and Ullah, S. (2015). Role of aflatoxin toxicity on transmissibility and pathogenicity of H9N2 avian influenza virus in turkeys. Avian Pathology 44(4), 305310.

Wang, H., Liu, W., Yu, F. and Lu, L. (2016). Identification of (-) epigallocatechin-3-gallate as a potential agent for blocking infection by grass carp reovirus. Archives of Virology 161, 1053-1059.

Weber, C., Sliva, K., von Rhein, C., Kümmerer, B. M. and Schnierle, B. S. (2015). The green tea catechin, epigallocatechin gallate inhibits chikungunya virus infection. Antiviral Research 113, 1-3.

Wei, Z. Q., Zhang, Y. H., Ke, C. Z., Chen, H. X., Ren, P. He, Y. L., Pei, H., Ma, D., Luo, J. and Meng, Z. (2017). Curcumin inhibits hepatitis B virus infection by down-regulating cccDNA-bound histone acetylation. World Journal of Gastroenterology 23(34), 6252-6260.

Wu, X., Zhai, X., Lai, Y., Zuo, L., Zhang, Y., Mei, X., Xiang, R., Kang, Z., Zhou, L. and Wang, H. (2019). Construction and immunogenicity of novel chimeric virus-like particles bearing antigens of infectious bronchitis virus and Newcastle disease virus. Viruses 11(3), 254.

Xu, J., Gu, W., Li, C., Li, X., Xing, G., Li, Y., Song, Y. and Zheng, W. (2016). Epigallocatechin gallate inhibits hepatitis $B$ virus via farnesoid $X$ receptor alpha. Journal of Natural Medicines 70(3), 584-591.

Yan, S., Zhao, J., Xie, D., Huang, X., Cheng, J., Guo, Y., Liu, C., Ma, Z., Yang, H. and Zhang, G. (2018). Attenuation, safety, and efficacy of a QX-like infectious bronchitis virus serotype vaccine. Vaccine 36(14), 1880-1886.

Yang, M., Lee, G., Si, J., Lee, S. J., You, H. J. and Ko, G. (2016a). Curcumin shows antiviral properties against norovirus. Molecules 21(10), 1401.

Yang, X. X., Li, C. M. and Huang, C. Z. (2016b). Curcumin modified silver nanoparticles for highly efficient inhibition of respiratory syncytial virus infection. Nanoscale 8(5), 3040-3048.

Yang, Z. F., Bai, L. P., Huang, W. B., Li, X. Z., Zhao, S. S., Zhong, N. S. and Jiang, Z. H. (2014). Comparison of in vitro antiviral activity of tea polyphenols against influenza $A$ and $B$ viruses and structure-activity relationship analysis. Fitoterapia 93, 47-53.
Zhao, Y., Cheng, J., Liu, X., Zhao, J., Hu, Y. and Zhang, G. (2015). Safety and efficacy of an attenuated Chinese QX-like infectious bronchitis virus strain as a candidate vaccine. Veterinary Microbiology 180(1-2), 49-58.

Zhu, L., Ding, X., Zhang, D., Yuan, C., Wang, J., Ndegwa, E. and Zhu, G. (2015). Curcumin inhibits bovine herpesvirus type 1 entry into MDBK cells. Acta Virologica 59(3), 221-227. 